\title{
Chemical Composition and Petrogenetic Implications of Apatite in the Khibiny Apatite-Nepheline Deposits (Kola Peninsula)
}

\author{
Lia Kogarko \\ Vernadsky Institute of Geochemistry and Analytical Chemistry, Russian Academy of Sciences, \\ Moscow 119991, Russia; kogarko@geokhi.ru
}

Received: 4 October 2018; Accepted: 8 November 2018; Published: 16 November 2018

check for updates

\begin{abstract}
Khibiny, one of the largest of the world's peralkaline intrusions, hosts gigantic apatite deposits. Apatite is represented by F-apatite and it contains exceptionally high concentration of SrO. (4.5 wt \% on average) and increased amounts of rare earth elements (REEs; up to $8891 \mathrm{ppm}$ ). Such enrichment of apatite ores in REEs defined Khibiny deposit as world-class deposit with resources reaching several millions tons $\mathrm{REE}_{2} \mathrm{O}_{3}$. Apatite from the Khibina alkaline complex is characterized by the significant enrichment in light REEs relative to the heavy REEs (with average $\mathrm{Ce} / \mathrm{Yb}$ ratio of 682) and the absence of a negative Eu anomaly. The obtained geochemical signature of apatite suggests a residual character of the Khibiny alkaline magma and it indicates that the differentiation of the primary olivine-melanephelinitic magma developed without fractionation of plagioclase which is the main mineral-concentrator of $\mathrm{Sr}$ and $\mathrm{Eu}$ in basaltic magmatic systems. The compositional evolution of the Khibiny apatite in the vertical section of the intrusion reflects primary fractionation processes in the alkaline magma that differentiated in situ. The main mechanism for the formation of the apatite-nepheline deposits was the gravitational settling of large nepheline crystals in the lower part of the magma chamber, while very small apatite crystals were suspended in a convective magma, and, together with the melt, were concentrated in its upper part of the magmatic chamber.
\end{abstract}

Keywords: apatite; Khibiny; apatite-nepheline deposit; phase diagram apatite-nepheline-diopside

\section{Introduction}

Apatite is a common accessory mineral and it has been extensively used to obtain significant genetic information [1-4]. This mineral is found in virtually all igneous rocks due to expanded crystallization fields. Experimental studies of the apatite solubility in the wide variety of silicate melt compositions have shown strong dependence of apatite saturation level upon silica activity and to a lesser extent concentration of $\mathrm{Al}, \mathrm{Fe}$, alkalis and oxygen fugacity [5]. Apatite is soluble in basic melts as compared to leucocratic magmas and its solubility in magmas decreases markedly with the increasing silica content and falling temperature [5,6]. Our experimental studies demonstrated the extremely high solubility of apatite in olivine melilite nephelinitic melts [6]. At a temperature of $1250{ }^{\circ} \mathrm{C}$, basaltic melt, containing $50 \% \mathrm{SiO}_{2}$ dissolves 3-4 wt $\% \mathrm{P}_{2} \mathrm{O}_{5}$, [5] and olivine melilite nephelinite, containing $41 \%$ $\mathrm{SiO}_{2}$ under the same conditions of $8-9 \% \mathrm{P}_{2} \mathrm{O}_{5}$. Previous detailed studies of Kola Alkaline Carbonatite Province (KACP) $[7,8]$ have established that the composition of primary magma corresponded to a sodic melilitite or olivine melanephelinite $\left(24.5-26.7 \% \mathrm{SiO}_{2}\right)[7,9,10]$. The mantle is generally P-depleted (86 ppm [11] and it only ultra-alkaline silica-undersaturated magmas produced at very low degrees of partial melting of metasomatised P-enriched mantle could then be saturated in apatite at near liquidus conditions. Highly undersaturated character of Kola primary magmas suggests the significant potential of $\mathrm{P}_{2} \mathrm{O}_{5}$ in alkaline rocks and carbonatites. Giant apatite deposits are associated with Khibiny peralkaline nepheline syenites. Khibiny ore deposits had been mined since 1930s. 
The formation of apatite deposits within KACP has been addressed in a large number of studies [4,12-17]. The, two leading models include separation of primary iiolite-urtite magma into two immiscible melts (phosphate and aluminosilicate) and the second hypothesis relates to the formation of apatite ores with processes of crystallization differentiation.

This paper is focused on the trace element composition of apatite from several Khibiny apatite-nepheline deposits. The trace elements, particularly Sr and REE, are used as effective monitors of the magmatic evolution leading to ore formation in Khibiny complex.

\section{Geological Setting}

The geology of the Khibiny alkaline complex has been described in a large number of publications $[4,14,16,18]$, and only a brief summary of the south-west apatite deposits is given here (Figures 1 and 2).

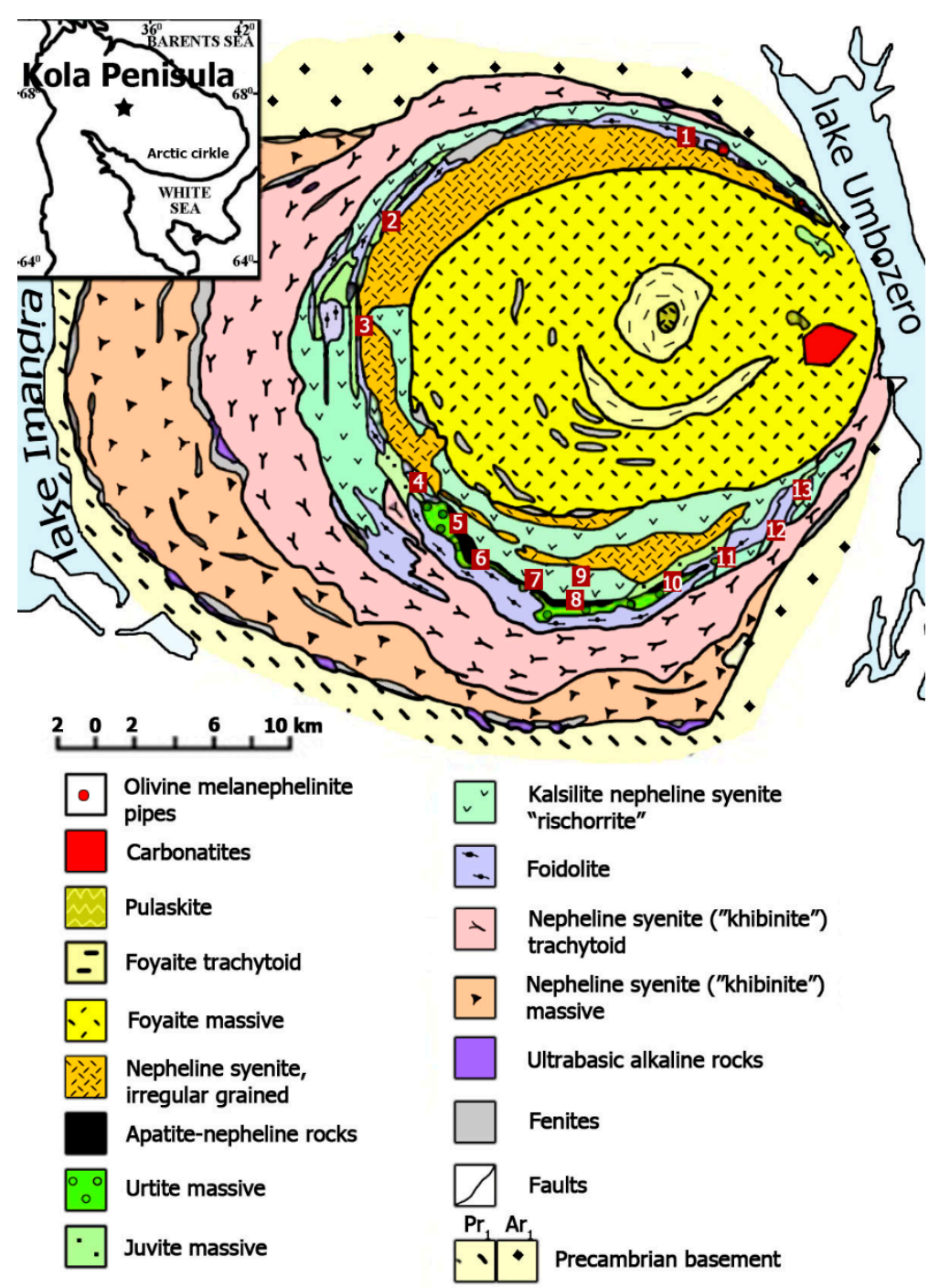

Figure 1. Geological map of the Khibiny massif generalized from the map of MGRE PGO "Sevzapgeologiya" (V.P.Pavlov) [2]. The geology of the Khibiny alkaline massif modified after using data from, and include references here [2]. $\square$-Titanite-Apatite deposits: 1-Valepakhk; 2-Partomchorr; 3-Kuelporr; 4-Snezhny Tsyrk; 5-Kukisvumchorr; 6-Yuksporr; 7-Apatitovy Tsyrk; 8-Rasvumchorr; 9-Eveslogchorr; 10-Koashva; 11-Vuonemyok; 12-Nyorkpakhk; 13-Oleny Ruchey [19]. 


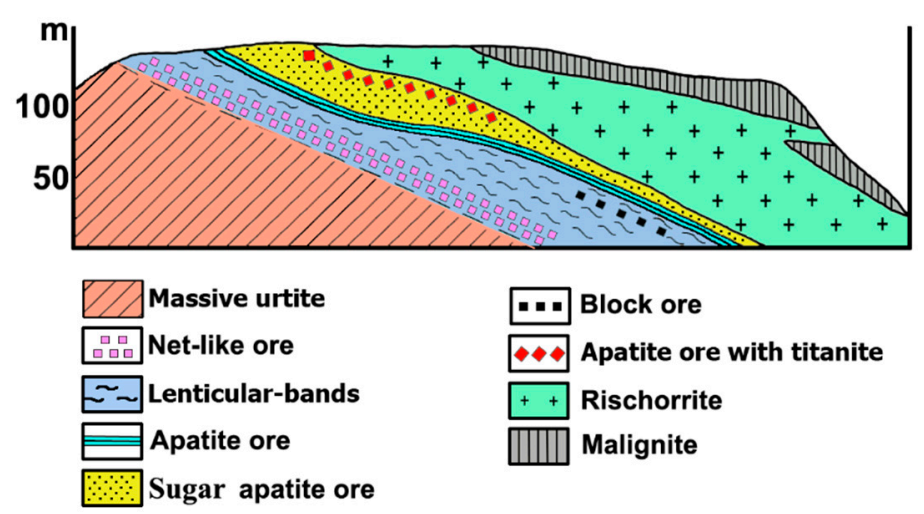

Figure 2. Cross-section of the Kukisvumchorr apatite deposit [14].

This complex is located in the central part of the Kola Peninsula, Russia, where it occurs as a ring intrusion of about $1325 \mathrm{~km}^{2}$.

The Khibiny alkaline massif is a complex multiphased body built up from a number of ring-like and conical intrusions (Figure 1). The oldest rocks tend to occur towards the margins with successively younger intrusions being encountered towards the center.

From the oldest to youngest, the igneous units are: I-nepheline and alkali syenites, nepheline syenite-porphyries, II-massive khibinites (coarse-grained nepheline syenites), III-trachytoid khibinites, IV—rischorrites (potassium-rich nepheline syenites), V-ijolites, melteigites, and urtites. (This intrusion comprises the well-known stratified complex of rocks which contains the world-class apatite ore deposits.) VI—medium-grained nepheline syenites, VII—foyaites, VIII—carbonatites.

The intrusion of ijolite-urtite is of special interest, because it hosts the apatite ores. The intrusion is cone-shaped and outcrops as a discontinuous ring with a diameter of 26-29 km and length of the order of $75 \mathrm{~km}$. The apatite-bearing intrusion has been separated into three subphases [14]. These are preore (I), ore (II), and post-ore (III) units. The rocks of subphase (I) consist of a series of ijolites interlayered with subordinate amounts of melteigite, urtite, juvite and malignite. Total thickness is less than $800 \mathrm{~m}$. Subphase (II) consists of massive feldspathic urtite, ijolite-urtite and apatite ore with a total thickness of 200 to $800 \mathrm{~m}$. The rocks of subphase (III) are from 10 to $1400 \mathrm{~m}$ thick and include lujavrite.

The principal phosphate ore deposits are found in subphase (II), where the apatite-rich rocks are found in the hanging wall of an ijolite-urtite intrusion (Figure 2).

The deposit is characterized by layering, as evidenced by distinct petrographic and geochemical features. The most upper parts of the apatite-rich bodies are composed of titanite-apatite ores $(\sim 18 \%$ titanite, $80 \%$ apatite, $2 \%$ titanomagnetite). The upper zone (rich apatite ore) is represented by patchy and patchy-banded, so called sugar apatite ore [14]. The rock consists of $60-90 \%$ euhedral apatite crystals of several tenths of $\mathrm{mm}$ in size (Figure 3). Interstitial minerals are clinopyroxene, titanite, $\mathrm{K}$-feldspar, titananagnetite, and nepheline. In some cases, the monomineralic layers of nepheline alternate with monomineralic apatite. The lower zone (poor apatite ore) is lenticular-banded, net-like and block ore. Lenticular-banded ore consists of fine-grained ijolite separated by layers of apatite and fine-grained urtite. Ijolite mainly consists of nepheline (up to $0.6 \mathrm{~mm}$ across) and pyroxene (up to $0.5 \mathrm{~mm}$ across). Net-like ore is texturally and structurally similar to lenticular-banded ore and differs from it only by the smaller proportion of urtite and apatite bands. Block ore appears pegmatitic. Occasional large crystals of nepheline (up to $15 \mathrm{~mm}$ across) occur in nepheline-apatite rock and in monomineralic apatite aggregates. The lowest zone grades into underlying massive urtite (Figure 2). The urtite consists of $75-90 \%$ large euhedral nepheline (up to 1-3 mm across) with intergranular acmitic clinopyroxene, titanite, feldspar, titanomagnetite, and aenigmatite (Figure 3). Extremely small grains of euhedral apatite are also found in the mesostasis. Massive urtites occupy about $89 \%$ of the thickness of the whole cross-section, whereas poor-ores and rich apatite ores occupy $8 \%$ and $3 \%$, respectively. The average composition of the apatite-bearing intrusion that was obtained as result of detail mapping is given in Table 1. Our isotopic study has established the age of the rocks and apatite ores Khibiny 
massif-370 Ma [20,21]. The initial Hf, Sr, Nd isotope ratios are similar to the isotopic signatures of OIB indicating depleted mantle as a source [21]. This leads to the suggestion that the origin of this gigantic alkaline intrusion and super large apatite deposits is connected to a deep seated mantle source and metasomatic interaction between mantle material and fluid-melts transporting phosphorus and rare elements into magma-generation zones [20].
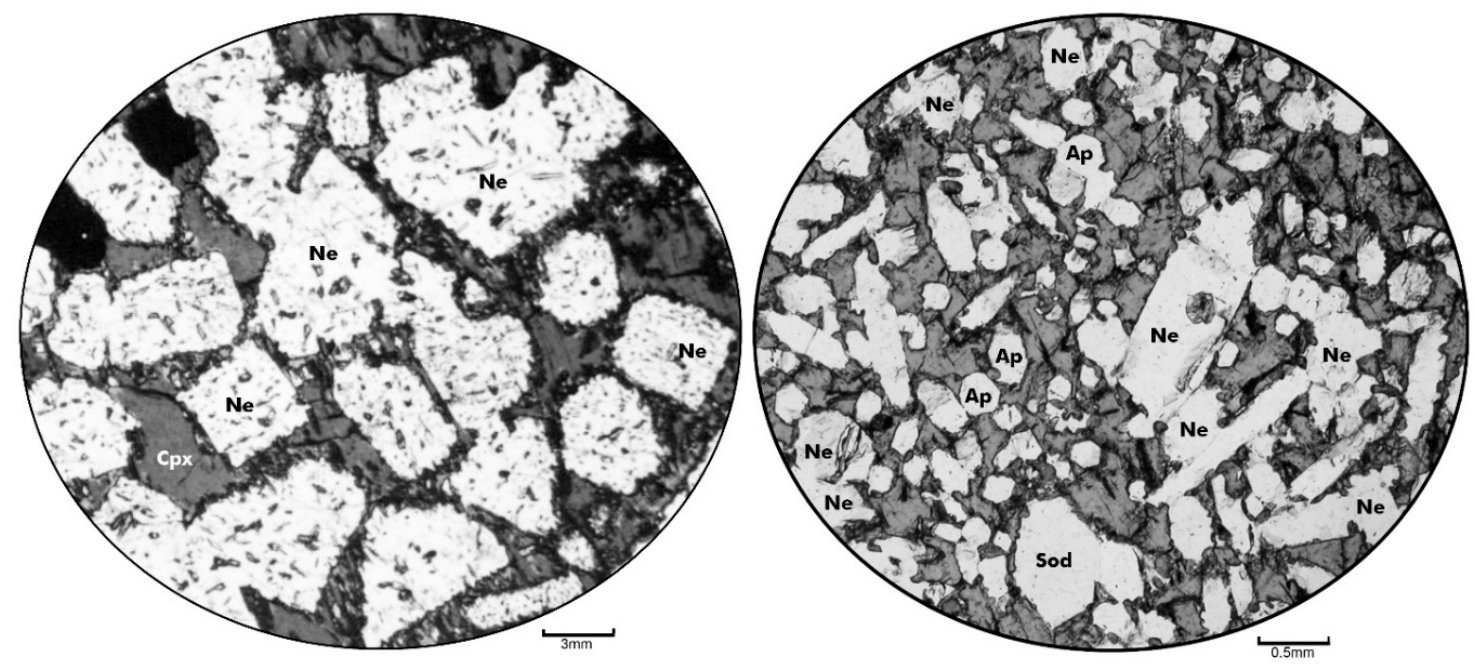

Figure 3. Thin sections of Khibiny apatite ore and massive urtite. Ne-nepheline Ap-apatite, Cpx-pyroxene, Sod-sodalite.

Table 1. Average composition of the apatite- bearing intrusion, wt \%: [22].

\begin{tabular}{ccccccccccccccccc}
\hline Element & $\mathrm{SiO}_{2}$ & $\mathrm{TiO}_{2}$ & $\mathrm{Al}_{2} \mathrm{O}_{3}$ & $\mathrm{Fe}_{2} \mathrm{O}_{3}$ & $\mathrm{FeO}$ & $\mathrm{MnO}$ & $\mathrm{MgO}$ & $\mathrm{CaO}$ & $\mathrm{Na}_{2} \mathrm{O}$ & $\mathrm{KO}$ & $\mathrm{SrO}$ & $\mathrm{BaO}$ & $\mathrm{P}_{2} \mathrm{O}_{5}$ & $\mathbf{F}$ & $\mathrm{H}_{2} \mathrm{O}$ & Total \\
\hline Average & 49.93 & 1.76 & 22.71 & 3.12 & 2.2 & 0.12 & 0.89 & 5.22 & 9.79 & 6.63 & 0.12 & 0.1 & 2.3 & 0.19 & 0.16 & 99.24 \\
\hline
\end{tabular}

\section{Composition of Khibiny Apatite}

Over 900 apatite grains from several Khibiny apatite deposits have been analyzed. The specimens were collected from drill holes of four Khibiny apaite deposits (Table 2). Rusvumchorr drill hole sampled a complete stratigraphic section through deposit. Samples of apatite of Kukisvumchorr and Nuorkpakhk deposits were obtained from surface outcrops.

Table 2. Examples of the distribution of elements in the apatites of various fields of Khibiny massif. $(1200 *$ analyses).

\begin{tabular}{cccccc}
\hline & $\begin{array}{c}\text { Rasvumchorr } \\
\text { (38 Samples) }\end{array}$ & $\begin{array}{c}\text { Oleniy Ruchey } \\
\text { (43 Samples) }\end{array}$ & $\begin{array}{c}\text { Koashva } \\
\text { (62 Samples) }\end{array}$ & $\begin{array}{c}\text { Yuksporr } \\
\text { (12 Samples) }\end{array}$ & Khibiny Massif \\
\hline Element & Average & Average & Average & Average & Average \\
\hline Ce/Yb & 441 & 705 & 940 & 416 & 682 \\
氵REE & 7451 & 7379 & 12,979 & 7218 & 8891 \\
Ce & 3334 & 3283 & 6086 & 3202 & 4040 \\
La & 2294 & 2247 & 4293 & 2152 & 2799 \\
Pr & 314 & 308 & 521 & 309 & 367 \\
Nd & 1085 & 1101 & 1637 & 1111 & 1243 \\
Sm & 150 & 157 & 182 & 156 & 162 \\
Eu & 41 & 44 & 45 & 45 & 44 \\
Gd & 113 & 120 & 117 & 122 & 118 \\
Tb & 13 & 14 & 12 & 64 & 13 \\
Dy & 62 & 64 & 52 & 10 & 60 \\
Ho & 10 & 10 & 8.3 & 21 & 9.8 \\
Er & 21 & 21 & 16 & 2.0 & 20 \\
Tm & 2.2 & 2.0 & 1.5 & 9.3 & 1.9 \\
Yb & 10 & 10 & 7.0 & & 8.9 \\
\hline
\end{tabular}


Table 2. Cont.

\begin{tabular}{cccccc}
\hline & $\begin{array}{c}\text { Rasvumchorr } \\
\text { (38 Samples) }\end{array}$ & $\begin{array}{c}\text { Oleniy Ruchey } \\
\text { (43 Samples) }\end{array}$ & $\begin{array}{c}\text { Koashva } \\
\text { (62 Samples) }\end{array}$ & $\begin{array}{c}\text { Yuksporr } \\
\text { (12 Samples) }\end{array}$ & Khibiny Massif \\
\hline Element & Average & Average & Average & Average & Average \\
\hline $\mathbf{L u}$ & 1.0 & 1.0 & 0.7 & 1.0 & 0.9 \\
$\mathbf{S i}$ & 1123 & - & - & - & 1123 \\
$\mathbf{N a}$ & 1100 & - & 1200 & - & 1150 \\
$\mathbf{S r}$ & 30,149 & 30,543 & 64,771 & 18,947 & 38,520 \\
$\mathbf{H f}$ & 0.02 & - & 0.1 & 0.1 & 0.1 \\
$\mathbf{T a}$ & 0.003 & - & 0.1 & 0.1 & 0.0 \\
$\mathbf{P b}$ & 1.4 & - & 1.0 & 1.4 & 1.2 \\
$\mathbf{T h}$ & 19 & - & 23 & 25 & 22 \\
$\mathbf{U}$ & 2.0 & - & 1.3 & 2.5 & 2225 \\
$\mathbf{M g}$ & - & 4181 & 22 & 58 & 1.6 \\
$\mathbf{S c}$ & 0.04 & 3 & 0.6 & 1.2 & 142 \\
$\mathbf{M n}$ & 150 & 157 & 114 & 136 & 182 \\
$\mathbf{F e}$ & 88 & 313 & 89 & 99 & 245 \\
$\mathbf{Y}$ & 283 & 265 & 171 & 277 & 6.6 \\
$\mathbf{Z r}$ & 2.3 & 8 & 7.2 & 7.1 & 0.4 \\
$\mathbf{N b}$ & 0.1 & 1 & 0.6 & 0.1 & 0.4 \\
$\mathbf{B a}$ & 331 & 418 & 318 & 326 & \\
$\mathbf{Z n}$ & 0.4 & - & - & - & \\
\hline & & $*$ & &
\end{tabular}

Samples were analyzed at the Vernadsky Institute of Geochemistry and Analytical Chemistry RAS, Moscow. Mineral compositions were determined using CAMECA SX 100 electron probe microanalyser (CAMECA, Gennevilliers, France) with four diffraction spectrometers at an accelerating voltage of $15 \mathrm{kV}$ and probe current of $60 \mathrm{nA}$. We used next natural and synthetic reference samples: for $P$ and $\mathrm{Ca}-$ apatite, for $\mathrm{Sr}-$ celestine, for $\mathrm{F}-\mathrm{LiF}$, for $\mathrm{Na}-$ jadeite, for $\mathrm{La}-\mathrm{La}_{2}\left(\mathrm{PO}_{4}\right)_{2}$, for $\mathrm{Ce}-\mathrm{Ce}_{2}\left(\mathrm{PO}_{4}\right)_{2}$. All standarts are from Smithsonian Institution. Concentrations were calculated from relative peak intensities using the PAP-correction.

Trace element analyses were performed in Frakfurt University and Max Plank Institute in Minze using a Thermo Scientific Element 2 ICPMS (Thermo Fisher, Waltham, MA, USA) coupled with a Resonetics Resolution M-50 excimer laser. The laser spot size varied from 20 to $60 \mu \mathrm{m}$. The following isotopes were used for determining the abundances of the elements: ${ }^{29} \mathrm{Si},{ }^{45} \mathrm{Sc},{ }^{88} \mathrm{Sr},{ }^{89} \mathrm{Y},{ }^{90} \mathrm{Zr},{ }^{93} \mathrm{Nb}$, ${ }^{137} \mathrm{Ba},{ }^{139} \mathrm{La},{ }^{140} \mathrm{Ce},{ }^{141} \mathrm{Pr},{ }^{146} \mathrm{Nd},{ }^{147} \mathrm{Sm},{ }^{151} \mathrm{Eu},{ }^{157} \mathrm{Gd},{ }^{159} \mathrm{~Tb},{ }^{161} \mathrm{Dy},{ }^{165} \mathrm{Ho},{ }^{167} \mathrm{Er},{ }^{169} \mathrm{Tm},{ }^{172} \mathrm{Yb},{ }^{175} \mathrm{Lu}$, ${ }^{178} \mathrm{Hf},{ }^{181} \mathrm{Ta},{ }^{208} \mathrm{~Pb},{ }^{232} \mathrm{Th},{ }^{55} \mathrm{Mn},{ }^{57} \mathrm{Fe}$, and ${ }^{24} \mathrm{Mg}$.

As the standarts we used NIST glasses. All samples were analysed on polished sections and done by the author with the help of Institutes staff.

Apatites have been extracted from different rocks of deposits and all types of ores. Apatite typically occurs as small $(0.1-0.3 \mathrm{~mm})$ well-defined idiomorphic rounded or acicular grains (Figure 3). The apatite is light yellow in colour or transparent. Apatite often contains numerous primary magmatic micro inclusions, mainly containing nepheline, K-feldspar, clinopyroxene, apatite, and titanite [23]. In the apatite ore, there are zones of large late apatite of dark color. Previous studies [24-27] have established that Khibiny apatite corresponds to fluorapatite according to new nomenclature [28]. In this paper we investigated in detail the trace element composition of Khibiny apatite from several deposits and various sections through ore bodies. We estimated average concentrations of Sr, REE (La, $\mathrm{Ce}, \mathrm{Yb}$ ), Na, Si, Th, U in apatites of some Khibiny deposits. (Table 2). Previous studies [24] have shown that the principal substitution mechanisms involve replacement of $\mathrm{Ca}^{2+} \mathrm{by} \mathrm{Sr}^{2+}$, and to a much smaller extent, $\mathrm{Mn}^{2+}$ and $\mathrm{Fe}^{2+}$ [24]. The main REE substitution is $\mathrm{REE}^{3+}+\mathrm{Si}^{4+}=\mathrm{Ca}^{2+}+\mathrm{P}^{5+}$, and $\mathrm{REE}^{3+}$ $+\mathrm{Na}^{+}=2 \mathrm{Ca}^{2+}$. The substitution $2 \mathrm{Ca}^{2+}<\mathrm{Na}^{+}+\mathrm{LREE}^{3+}$ is quite rare in apatites and it occurs in highly alkaline igneous systems [29].

Petrographic study demonstrated that apatite was an early liquidus phase in ores and rocks of ijolite-urtite intrusion. 
Our study showed that the majority of analyzed apatite grains are homogeneous with respect to the distribution of trace elements. The pronounced zonation of apatite crystals was not detected. In some cases, a subtle zoning is observed in apatites from the Oleniy Ruchey and Yukspor deposits where $\mathrm{Sr}$ and Ce levels increase from central to the marginal zones of apatite crystals. ( $\mathrm{SrO}-2.1-3.5 \mathrm{wt} \%, 1.7-2.1 \mathrm{wt} \%, \mathrm{Ce}_{2} \mathrm{O}_{3}-0.25-0.37 \mathrm{wt} \%$, and $0.3-0.36 \mathrm{wt} \%$ ).

In several apatite grains from the Oleniy Ruchey ores a reverse zonation with respect to $\mathrm{Ce}_{2} \mathrm{O}_{3}$ was recorded (0.32-0.25 wt \%, 0.13-0.096 wt \%).

Khibiny apatite contains exeptionaly high levels of $\mathrm{SrO}$ (4.5 wt \% on average), which varies markedly within $0.16-9.8 \mathrm{wt} \%$ in different ore deposits. The concentration of $\mathrm{Sr}$ in apatite is much higher compared to the host magma (0.2 wt \% [9]). We investigated the composition of apatite in the vertical section (up to $600 \mathrm{~m}$ depth) of the Rasvumchorr deposit. Despite significant variations in the concentrations of $\mathrm{Sr}$ in apatites at the same level, an increase in the content of Sr upwards is observed along the borehole crossection (Figure 4). Cryptic layering of $\mathrm{Sr}$ in Khibiny apatite is not as pronounced as for example in loparite in a nearby alkaline Lovozero massif.
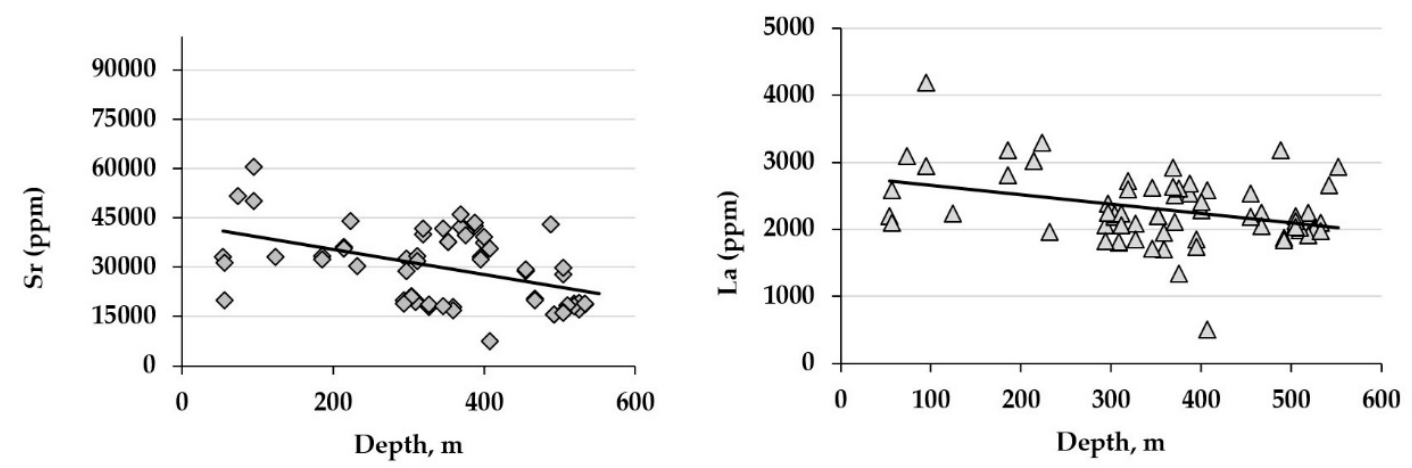

Figure 4. Distribution of Sr, La in apatite in the vertical section of Rasvumchorr deposit.

Apatite and titanite are the main minerals that host REE in the Khibiny deposits. The total REE content in apatite ranges from hundredths of percent to over $1.5 \%$ with an average of $8891 \mathrm{ppm}$. Such concentration of rare earth in millions of tons of apatite ores defined Khibiny deposit as world-class with resources $5.5 \mathrm{Mt} \mathrm{REE}_{2} \mathrm{O}_{3}$ [30]. Chondrite-normalized REE plots (Figure 5) of Khibiny apatites demonstrated significant enrichment of the light rare earths over heavy $\mathrm{REE}, \mathrm{Ce} / \mathrm{Yb}$ is very high with an average of 682. It is worth noting that all chondrite-normalized REE plots of apatite lack negative Eu anomaly (Figure 5). This confirms our conclusion [31] that the oxygen fugacities of apatite-bearing intrusion of the Khibiny complex were close to the QFM buffer system and apatite contained $\mathrm{Eu}^{3+}$.

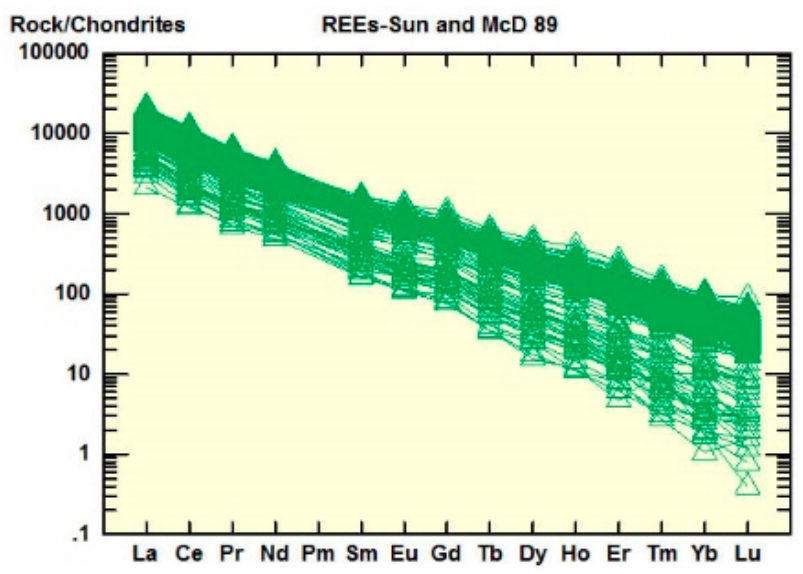

Figure 5. Distribution of REE in Khibiny apatite. 
The Eu anomaly and levels of $\mathrm{Sr}$ are also controlled by the plagioclase which concentrate $\mathrm{Eu}^{2+}$ from the melt $\left(\mathrm{Kd}^{\mathrm{Eu}}\right.$ in plagioclase-3.8-7.9 [32], $\mathrm{Kd}^{\mathrm{Sr}}-2.7-10$ [33]. In the process of crystallization differentiation of KACP primary magma of olivine nephelinites composition plagioclase did not crystallize plagioclase. Main minerals of this process, such as olivine, melilite and clinopyroxene do not typically concentrate $\mathrm{Eu}$ and $\mathrm{Sr}$, because of the very low distribution coefficients of $\mathrm{Eu}$ and $\mathrm{Sr}$ in these minerals [32,34]. We studied the distribution of Ce in the vertical section of the Rasvumchorr deposit drillhole. Ce contents in apatite increase systematically upwards through $600 \mathrm{~m}$ of the apatite-nepheline deposit (Figure 4). The compositional evolution of apatite reflects primary fractionation processes in the alkaline magma that differentiated in situ from the bottom to the top of the magma chamber. The contents of $\mathrm{Mn}, \mathrm{Fe}$, and $\mathrm{Mg}$ in apatites are low and vary within a considerable range (Mn-30-250 ppm, $\mathrm{Fe}-89-1153 \mathrm{ppm}, \mathrm{Mg}-22-4420 \mathrm{ppm}$ ). The majority of coarse-grained dark color apatite grains contains slightly elevated levels of $\mathrm{Fe}, \mathrm{Mn}$, and $\mathrm{Mg}$, while the concentration of rare earths is similar to that of the light-yellow apatite, which is most common.

The concentration of radiactive elements in Khibiny apatite is low (average Th-22 ppm, U-1.8 ppm) relative to other alkaline complexes (e.g., Lovozero, Pilansberg) Table 2.

In some cases, $\mathrm{Sr}$ apatites may contain some $\mathrm{Ba}$, for example, the Pilansberg apatite from alkaline complex (South Africa) contains up to 2500 ppm Ba [29]. Khibiny apatite contains significantly lower concentrations of barium on average $363 \mathrm{ppm}$. Relative to apatites from several other localities, including Pilansberg [29] and Lovozero [25], apatite from Khibiny is depleted in rare earths and radioactive elements (Table 2). The concentrations of Sr in the Khibiny apatite are comparable to those from Lovozero, Pilansberg and Ilimaussaq. Notably, the highly alkaline complexes typically host belovite, this mineral was not found in the apatite-nepheline ores of Khibiny.

Compositionally, most of the studied apatites correspond to fluorapatites [28]. Fluorine content varies from 4.73 to $3.33 \mathrm{wt} \%$. The chlorine concentration is very low-hundredths of a percent.

The large amount of data accumulated during recent decades has shown that composition of apatite from different rocks of the world have distinctive absolute abundances of many trace elements and chondrite-normalized trace-element patterns [4,35,36]. Apatite global data-base [37] can be used for the identification of apatites from different rock types and processes of mineralization.

To establish the geochemical signature of Khibiny apatites, we used previously published data [37-39] and several discrimination plots, including Sr versus $\mathrm{Y}$, Sr versus $\mathrm{Mn}$, and $\mathrm{Ce} / \mathrm{Yb}$ versus REE (Figure 6). Apatites from different rock types plot within well-defined compositional fields on the majority of these diagrams [37]. According to our data, apatite from that the Khibiny complex is characterized by the highest levels of Sr among all rock varieties (Figure 6). It should be noted that apatite from the Khibiny complex shows characteristically low levels of $Y$ and heavy REEs, especially in comparison with the $\mathrm{Si}$ rich granitoids (Figure 6). Mn value is close to that of apatite from carbonatites and much lower relative to granitoids, granitic pegmatites, jacupirangites, and dolirites [37].

Khibiny apatite is considerably enriched in light relative to heavy REEs and has the highest $\mathrm{Ce} / \mathrm{Yb}$ ratio (Figure 6).

The obtained geochemical signature of Khibiny apatite suggests a residual character of the Khibiny alkaline magma and it indicates that the differentiation of the primary magma developed without fractionation of mineral-concentrators of $\mathrm{Sr}$ and $\mathrm{Eu}$ (such as plagioclase). Our data confirm previous findings regarding the olivine-nephelinitic nature of the primary magma of Khibiny apatite intrusion [7-10]. 


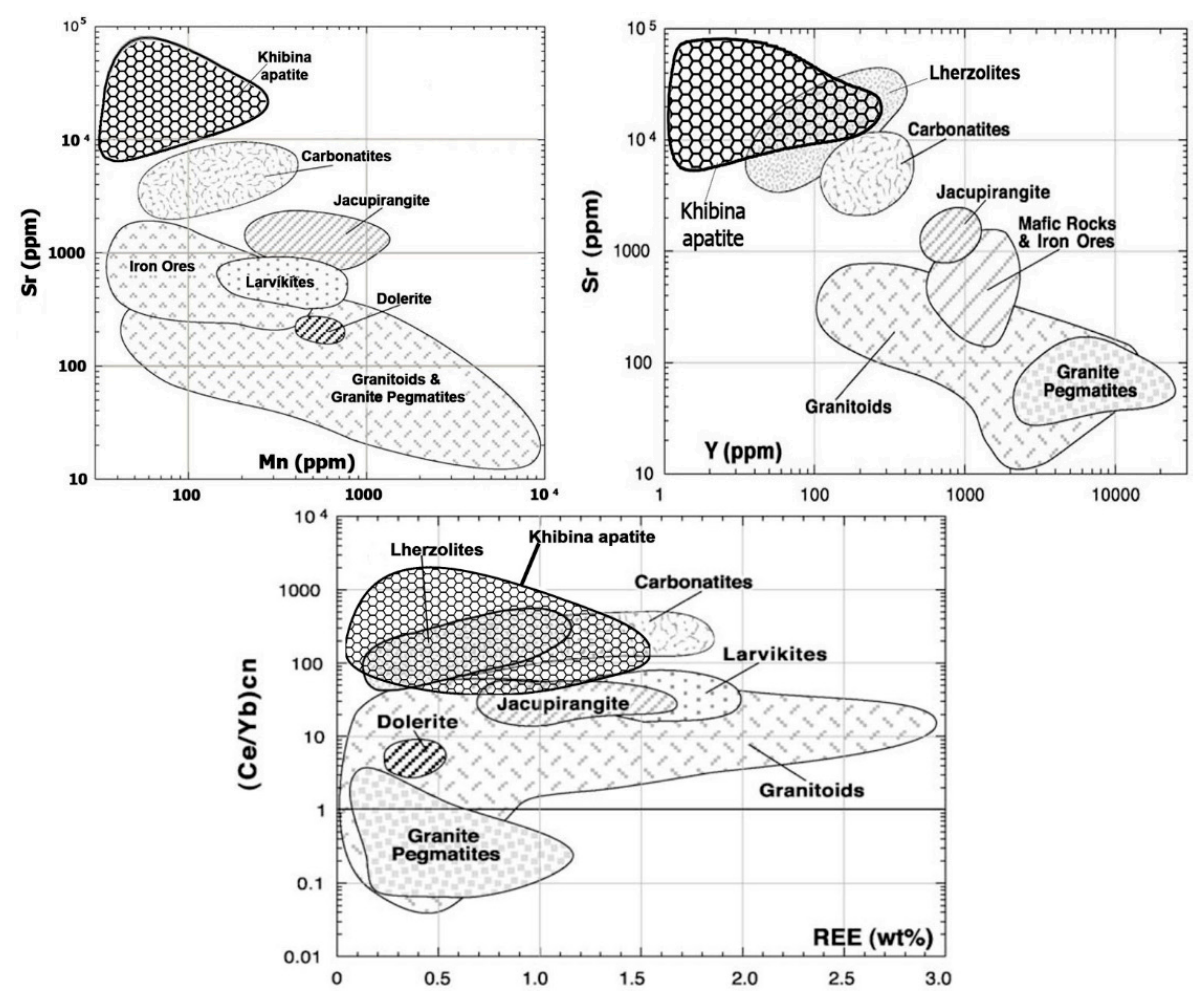

Figure 6. Compositional Field of Khibiny apatite on the discriminant diagrams proposed by [37].

\section{Genetic Problems of the Khibiny Apatite Deposits}

Apatite saturation in the magma mainly depends on its $\mathrm{P}_{2} \mathrm{O}_{5}$ content and to a lesser extent on composition of magma. At upper mantle pressure and a temperature of $1250{ }^{\circ} \mathrm{C}$ basaltic melt $(50 \%$ $\mathrm{SiO}_{2}$ ) will dissolve up to $4 \% \mathrm{P}_{2} \mathrm{O}_{5}$ before apatite saturation is reached [6]. According to [7,8,10,40], the $\mathrm{P}_{2} \mathrm{O}_{5}$ content of Devonian Kola primitive magmas $\left(28-32 \% \mathrm{SiO}_{2}\right)$ was in the range from 0.3 to $1.2 \mathrm{wt} \% \mathrm{P}_{2} \mathrm{O}_{5}$ and was not saturated in apatite. In the process of long evolution of primary alkaline magmas, the phosphorus content increased significantly and in Khibiny apatite intrusion it reaching $2.4 \%$ [22].

Extensive studies of fluid microinclusions in rock-forming minerals and phase equilibria of apatite-bearing systems were performed previously in order to establish the physico-chemical conditions of apatite ore formation $[17,23]$. According to these studies, primary inclusions were formed as a result of melt entrapment and they contain polyphase aggregates composed of sodalite, microcline, apatite, lepidomelan, pyroxene, iron sulfide, and villiaumite [23]. Thermometric experiments demonstrated that the melt appeared at a temperature of about $700{ }^{\circ} \mathrm{C}$; at gradual heating up to $900{ }^{\circ} \mathrm{C}$, villiaumite, microcline, mica, sulfides, sodalite, pyroxene, and sphene were completely resorbed and the microinclusions contained the equilibrium association melt + apatite + nepheline + gas. All phases were completely dissolved at $970{ }^{\circ} \mathrm{C}$, while the inclusions were homogenized and they contained only aluminasilicate melt. The microprobe analysis of the homogenized inclusions showed that aluminasilicate melt contained about $2 \mathrm{wt} \% \mathrm{P}_{2} \mathrm{O}_{5}$ [23], this value is close to the average for apatite-nepheline intrusion.

The phase equilibria of the apatite-bearing ijolite-urtite rocks of Khibiny can be approximated in the system $\mathrm{NaAlSiO}_{4}-\mathrm{CaMgSi}_{2} \mathrm{O}_{6}-\mathrm{Ca}_{5}\left(\mathrm{PO}_{4}\right)_{3} \mathrm{~F}$ (Figure 7) [9]. Composition (Table 1) represents a weighted average of the bulk composition of the apatite-bearing complex under consideration (Table 1 and Figure 2). From melt of such a composition nepheline would crystallize first. Apatite and nepheline would be the next to crystallize as the temperature falls. Apatite, nepheline, and pyroxene begin to precipitate as the temperature is lowered further. This crystallization sequence is in agreement with petrographic observations of the rocks [16]. Thus, from the viewpoint of experimental phase 
equilibria, an alumina-silicate melt with $2.4 \mathrm{wt} \% \mathrm{P}_{2} \mathrm{O}_{5}$ could have been the parental magma of the ore apatite complex. Such a magma would crystallize about $10-15 \%$ of nepheline before reaching the nepheline apatite-pyroxene cotectic and all these minerals would crystallize simultaneously. The close to eutectic character of apatite-bearing intrusion and the coincidence of the order of crystallization of apatite ores with the regularities of crystallization of experimentally studied phosphate-silicate systems indicate that the main process in the formation of apatite deposits was crystallization differentiation. It should be pointed out that field of existence of two liquids-phosphate and aluminosilicate (Figure 7) is separated from the average composition of apatite intrusion by the temperature barrier, which means that the "immiscibility" model $[12,13]$ is not realistic. In addition, the temperature of melting of monomineral apatite ore should be higher than $1500{ }^{\circ} \mathrm{C}$.

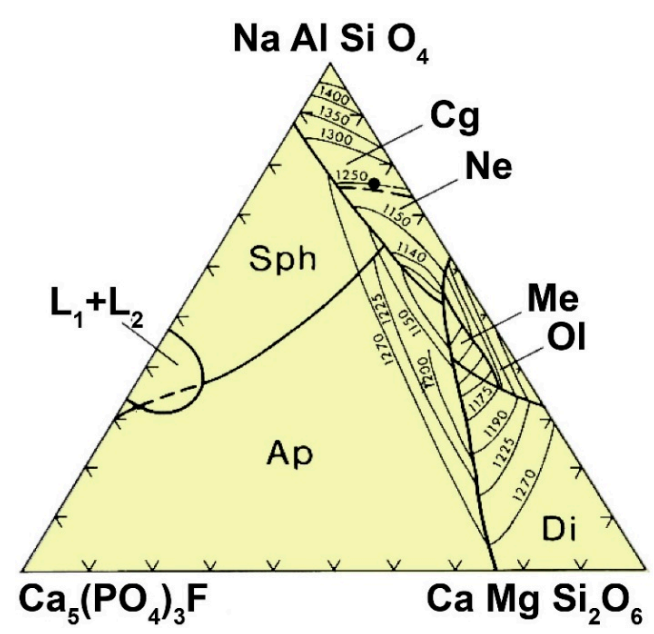

Figure 7. Phase relations in the system $\mathrm{NaAlSiO}_{4}-\mathrm{CaMgSi}_{2} \mathrm{O}_{6}-\mathrm{Ca}_{5}\left(\mathrm{PO}_{4}\right)_{3} \mathrm{~F}$ at 1 atm. pressure [9]. Cg-carnegieite, $\mathrm{Ne}$-nepheline, $\mathrm{Ol}$-olivine, $\mathrm{Me}$-melilite, $\mathrm{Di}$-diopside, Ap-apatite, Sph-silicophosphate, $\mathrm{L}_{1}+\mathrm{L}_{2}$-two immiscible liquids, - -average composition of the apatite-bearing intrusion.

As it has been demonstrated by a number of authors [41-44], a convective regime must exist in magmatic reservoirs with thickness exceeding $10 \mathrm{~m}$. However, the style of the convection with crystallization is likely steady-state conditions [45].

One outstanding problem that is presented by the apatite-ore bodies concerns the manner in which accumulation of nepheline, apatite and pyroxene occurs in terms of steady-state convection.

The consideration of the values of the velocity of sedimentation calculated according to Stokes law and viscosity, temperature difference, densities, and heat-conductivity gives [44]:

$$
\ln \frac{N_{p_{1}}}{N_{p_{2}}}=-0.66 \Delta \rho \rho^{-\frac{2}{3}} \eta^{-2} k^{-\frac{2}{3}} \alpha^{-\frac{1}{3}} \Delta T^{-\frac{1}{3}} C_{p}^{-\frac{1}{3}} g^{\frac{1}{3}} \mathrm{a}^{2}
$$

where:

$\Delta \rho=\rho_{s}-\rho_{l}$ the difference between densities of melt and crystals $\left(\mathrm{g} \mathrm{cm}^{-3}\right)$;

$\eta$ viscosity (poise);

$k$ coefficient of heat-conductivity $\left(\mathrm{cal} \mathrm{cm}^{-1} \mathrm{~s}^{-1} \mathrm{k}^{-1}\right)$;

$\alpha$ thermal expansion coefficient $\left(\mathrm{k}^{-1}\right)$;

$\Delta T$ temperature difference between roof and foot-wall;

$C_{p}$ heat-capacity (cal.g ${ }^{-1} \mathrm{k}^{-1}$ );

$g$ gravity acceleration $\left(980 \mathrm{~cm} \mathrm{~s}^{-2}\right)$; and,

a dimensions of crystals $(\mathrm{cm})$.

$N_{P 1} / N_{P 2}$-mineral particle number ratio near the roof and the floor of the magma chamber. 
This equation shows that the strongest influence on the distribution of particles is that of their size; with particles above a certain size-nepheline (up to $3-5 \mathrm{~mm}$ across), the stirring effect of the convection ceases to act and the particles are settled to the bottom of the magma chamber, forming a lower cumulus layer (massive urtite), while smaller particles-apatite (up to several tenths of $\mathrm{mm}$ ) are stirred more efficiently and enrich the later (upper) cumulative layers (rich apatite ore).

Very important is the presence of sorting of minerals [2] which suggests that the mechanism of accumulation of minerals and formation of apatite ores was the gravitational differentiation of the close to eutectic apatite- intrusion in conditions of convective motion. Sorting coefficients of apatite, nepheline, and pyroxene (Figure 8) are close to unit. Such values of sorting coefficients are characteristic of well-sorted sedimentary deposits, for instance, sands. According to the calculations, pyroxenes should accumulate in the middle part of apatite deposits, which corresponds to the distribution of this mineral in the vertical section of deposits. In the formation of massive urtites, very small apatite crystals were suspended and captured by the interstitial melt, demonstrating a significant difference in the sizes of these minerals in the early stages of crystallization (Figure 9). Thus crystals of apatite remained in suspension until the settling velocity is small as compared with the velocity of convective currents. At cooling of intrusion convection falls and even the small crystals of apatite forms accumulations and ores. This model is supported by the composition of Khibiny apatite. Very homogeneous character of Khibiny apatite and weakly expressed zoning suggest crystallization of apatite in a large volume of magmatic chamber, in which inevitably there is strong convection leading to active mixing.
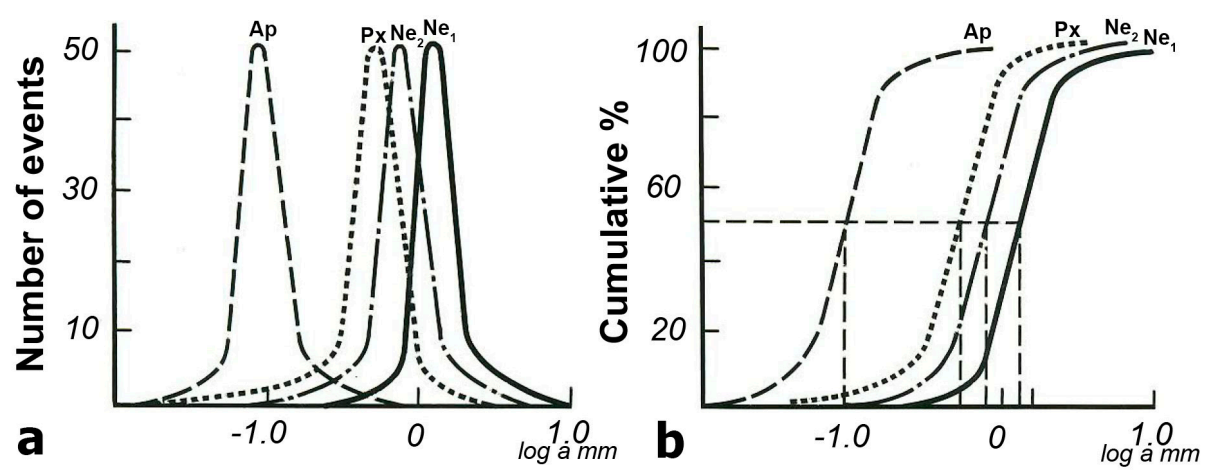

Figure 8. (a) Distribution diagrams for various minerals; (b) Calculated cumulative diagrams for minerals. Ap—apatite from rich apatite ore; $\mathrm{Px}$ —clinopyroxene from lenticular-banded and net- like ore (poor apatite ore); $\mathrm{Ne}_{2}$-nepheline from ores; $\mathrm{Ne}_{1}$-nepheline from massive urtite; a-diameter of mineral.

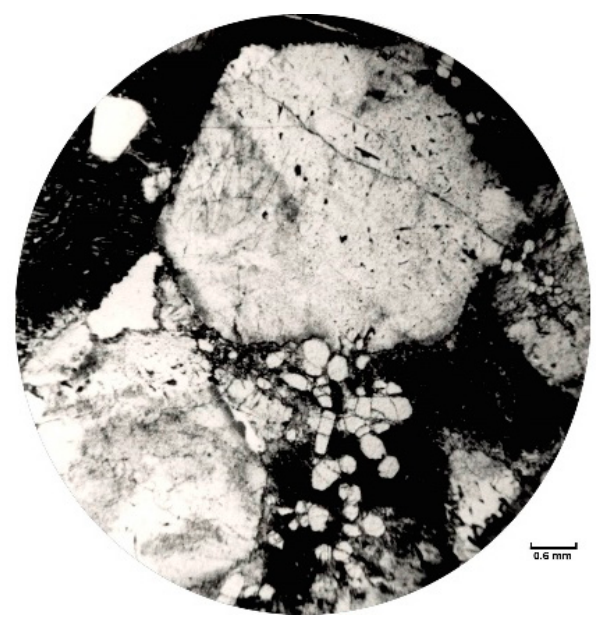

Figure 9. Thin section of massif urtite. Small crystals of apatite in interstitial between large crystals of nepheline. 
Our study demonstrated that in the cross-section of Rasvumchorr deposit the concentrations of Sr, $\mathrm{Ce}$, and La in apatite systematically increase with the increasing stratigraphic height (Figure 4). In the huge alkaline magmatic chamber of Etna (Italy) volcanic system, the content of REE in apatite also increases with the degree of differentiation [3]. The compositional evolution of the Khibiny apatite reflects the primary fractionation processes in the alkaline magma that differentiated from the bottom to the top of the magma chamber as a result of magmatic convection, coupled with the settling of minerals with different settling velocities. Compositional variations in apatite record subtle changes in the composition of alkaline magma. The cryptic variation observed in the Khibiny apatites appears to be very similar to that in minerals from basic layered intrusions [46,47]. The character of this cryptic layering suggests that fractional crystallization in situ of a single batch of alkaline magma was the main process governing the formation of the layered Khibiny apatite-nepheline intrusion. It should be noted that the ijolite dyke containing angular xenoliths of apatite ores and massive urtite cross-cuts the apatite intrusion. Also, active processes of post-ore tectonics took place and they caused the formation of numerous folds in the apatite deposits and displacements in the plastic state.

\section{Conclusions}

1. Our data show that apatite from the Khibiny complex is enriched in $\mathrm{SrO}(4.5 \mathrm{wt} \%$ ) and REEs- (up to $8891 \mathrm{ppm})$. Such concentration of rare earth in millions of tons of apatite ores defined Khibiny deposit as world-class with resources several millions tons $\mathrm{REE}_{2} \mathrm{O}_{3}$.

2. Statistical analysis showed that Khibiny apatites demonstrated a significant enrichment of the light rare earths over heavy REE (average $\mathrm{Ce} / \mathrm{Yb}$ ratio 682) and absence of negative Eu anomaly.

3. The obtained geochemical signature of Khibiny apatite suggests a residual character of the Khibiny alkaline magma and indicate that the differentiation of the primary olivine-melanephelinitic magma developed without fractionation of plagioclase which is the main mineral-concentrator of $\mathrm{Sr}$ and $\mathrm{Eu}$ of basaltic magmatic systems.

4. The compositional evolution of the Khibiny apatite in the vertical section of the intrusion reflects primary fractionation processes in the alkaline magma that differentiated in situ from the bottom to the top of the magma chamber as a result of magmatic convection, coupled with the precipitation of minerals with different settling velocities.

5. Our data suggest that the main mechanism for the formation of the apatite-nepheline deposits was the gravitational settling of large nepheline crystals the low part, while very small apatite crystals were suspended in a convective magma and, together with the melt, were concentrated in the upper part of the magmatic chamber.

Acknowledgments: I thank Kononkova N.N., Lahaye Y, Kuzmin D. for the help for sample analyses. The comments by 3 anonymous referees are much appreciated. This work is supported by the Program of RAS I.48 no. 0137-2018-0041.

Conflicts of Interest: The authors declare no conflict of interest.

\section{References}

1. Chakhmouradian, A.R.; Reguir, E.P.; Mitchell, R.H. Strontium-apatite: New occurrences, and the extent of Sr-for-Ca substitution in apatite-group minerals. Can. Miner. 2002, 40, 121-136. [CrossRef]

2. Kalashnikov, A.O.; Konopleva, N.G.; Pakhomovsky, Y.A.; Ivanyuk, G.Y. Rare Earth Deposits of the Murmansk Region, Russia-A Review. Soc. Econ. Geol. Inc. Econ. Geol. 2016, 111, 1529-1559. [CrossRef]

3. Busa, T.; Clochiatti, R.; Cristofolini, R. The role of apatite fractionation and REE distribution in alkaline rocks from Mt. Etna, Sicily. Miner. Pet. 2002, 74, 95-114. [CrossRef] 
4. Borutzky, B.E. Modern Understanding of the Nature and Geological History of the Formation of Rocks of the Khibiny Alkaline Massif. (Critical Comparison of the Proposed Hypotheses and Comments to Them). In Proceedings of the Materials of the All-Russian (with International Participation) Field Conference Dedicated to the 80th Anniversary of the Kola Science Centre RAS, Apatity, Russia, 20-23 June 2010; Geological Institute KSC RAS, Kola Branch of Russian Mineralogical Society: Apatity, Russia, 2010.

5. Watson, E.B. Apatite and phosphorus in mantle source regions: An experimental study of Apatite/melt equilibria at pressures to $25 \mathrm{kbar}$. Earth Planet. Sci. Lett. 1980, 51, 322-335. [CrossRef]

6. Kogarko, L.N.; Krigman, L.D.; Krot, T.V.; Ignatenko, K.I. Influence of chemical composition of magmatic melt on the solubility of $\mathrm{P}_{2} \mathrm{O}_{5}$. Geochem. Int. 1986, 10, 138.

7. Arzamastsev, A.A.; Bea, F.; Glaznev, V.N.; Arzamastseva, L.V.; Montero, P. Kola alkaline province in the Paleozoic: Evaluation of primary mantle magma composition and magma generation conditions. Russ. J. Earth Sci. 2001. [CrossRef]

8. Downesa, H.; Balaganskaya, E.; Beard, A.; Liferovich, R.; Demaiffe, D. Petrogenetic processes in the ultramafic, alkaline and carbonatitic magmatism in the Kola Alkaline Province: A review. Lithos 2005, 85, 48-75. [CrossRef]

9. Kogarko, L.N. Genetic Problems of Agpaitic Magmas; Nauka: Moscow, Russia, 1977; 294p. (In Russian)

10. Dunworth, E.; Bell, K. The Turiy Massif, Kola Peninsula, Russia: Isotopic and Geochemical Evidence for Multi-source Evolution. J. Pet. 2001, 42, 377-405. [CrossRef]

11. Palme, H.; O’Neill, H.S.C. Cosmochemical Estimates of Mantle Composition. In Treatise on Geochemistry; Holland, H.D., Turekian, K.K., Eds.; Elsevier: Amsterdam, The Netherlands, 2003.

12. Marakushev, A.A.; Suk, N.I. Experimental modeling of the Khibiny layered nepheline-syenite massif to clarify the genesis of apatite deposits. Russ. J. Earth Sci. 1993, 330, 241-244.

13. Suk, N.I. Liquid immiscibility in P-bearing melts as for the genesis of apatite deposits. Petrologiya 1993, 1, 282-291.

14. Zak, S.L.; Kamenev, E.A.; Minakov, P.V.; Armand, A.L.; Mikheichev, A.S.; Petersilie, J.A. The Khibiny Alkaline Massif; Nedra Publishers: Leningrad, Russia, 1972. (In Russian)

15. Kogarko, L.N.; Khapaev, V.V. The modelling of formation of apatite deposits of the Khibiny massif (Kola peninsula). In Origins of Igneous Layering; D. Reidel Publishing Company: Dordrecht, The Netherlands, 1987; pp. 589-611.

16. Ivanova, T.N.; Dudkin, O.B.; Kosyreva, L.V.; Polyakov, K.I. Ijolite-Urtites of the Khibiny Massif; Nauka Publish. House: Leningrad, Russia, 1970. (In Russian)

17. Kogarko, L.N. Ore-forming potential of alkaline magmas. Lithos 1990, 26, 167-175. [CrossRef]

18. Eliseev, N.A. The Khibine apatite deposits. Zap. RMO 1937, 66, 491-516. (In Russian)

19. Arzamastsev, A.A.; Yakovenchuk, V.N.; Pakhomovsky, Y.A.; Ivanyuk, G.Y. The Khibiny and Lovozero Alkaline Massifs: Geology and Unique Mineralization; 33 IGS Excursion, 47; Geological Institute of the Russian Academy of Science: Apatity, Russia, 2008.

20. Kogarko, L.N.; Lahaye, Y.; Brey, G.P. Plume-related mantle source of super-large rare metal deposits from the Lovozero and Khibiny massifs on the Kola Peninsula, Eastern part of Baltic Shield: Sr, Nd and Hf isotope systematics. Miner. Pet. 2010, 98, 197-208. [CrossRef]

21. Kramm, U.; Kogarko, L. Nd and Sr isotope signatures of the Khibiny and Lovozero agpaitic centres, Kola Alkaline Province, Russia. Lithos 1994, 32, 225-242. [CrossRef]

22. Minakov, F.V.; Kamenev, E.A.; Kalinkin, M.M. On original composition and evolution of ijolite-urtite magma from the Khibiny alkaline massif. Int. Geochim. 1967, 8, 901-915.

23. Kogarko, L.N.; Romanchev, B.P. Geochemical criteria of ore potential of alkaline magmas. Geochem. Int. 1986, 10, 1423-1430.

24. Pushcharovsky, D.Y.; Nadezhina, T.N.; Khomyakov, A.P. Crystal structure of strontium-apatite from Khibiny. Crystallogr. Rep. 1987, 32, 891-895. (In Russian)

25. Chakhmouradian, A.R.; Reguir, E.P.; Zaitsev, A.N.; Couëslan, C.; Xu, C.; Kynický, J.; Mumin, A.H.; Yang, P. Apatite in carbonatitic rocks: Compositional variation, zoning, element partitioning and petrogenetic significance. Lithos 2017, 274, 188-213. [CrossRef]

26. Pekov, I.V.; Chukanov, N.V.; Eletskaya, O.V.; Khomyakov, A.P.; Menshikov, Y.P. Belovite-(Ce): New data, refined formula, and relationships with other minerals of apatite group. Zap. Vserossiiskogo Miner. Obshchestva 1995, 124, 98-110. (In Russian) 
27. Khomyakov, A.P. Mineralogy of Hyperagpaitic Alkaline Rocks; Clarendon Press: Oxford, UK, 1995.

28. Pasero, M.; Kampf, A.R.; Ferraris, C.; Pekov, I.V.; Rakovan, J.; White, T.J. Nomenclature of the apatite supergroup minerals. Eur. J. Miner. 2010, 22, 163-179. [CrossRef]

29. Liferovich, R.P.; Mitchell, R.H. Apatite-group minerals from nepheline syenite, Pilansberg alkaline complex, South Africa. Miner. Mag. 2006, 70, 463-484. [CrossRef]

30. Zaitsev, A.; Williams, T.; Jeffries, T.; Strekopytov, S.; Moutte, J.; Ivashchenkova, O.; Spratt, J.; Petrovd, S.; Wall, F.; Seltmann, R.; et al. Rare earth elements in phoscorites and carbonatites of the Devonian Kola Alkaline Province, Russia: Examples from Kovdor, Khibiny, Vuoriyarvi and Turiy Mys complexes. Ore Geol. Rev. 2014, 61, 204-225. [CrossRef]

31. Ryabchikov, I.D.; Kogarko, L.N. Magnetite compositions and oxygen fugacities of the Khibiny magmatic system. Lithos 2006, 91, 35-45. [CrossRef]

32. Villemant, B.; Jaffrezic, H.; Joron, J.L.; Treuil, M. Distribution Coefficients of Major and Trace-Elements-Fractional Crystallization in the Alkali Basalt Series of Chaine-Des-Puys (Massif Central, France). Geochim. Cosmochim. Acta 1981, 45, 1997-2016. [CrossRef]

33. Kuehner, S.M.; Laughlin, J.R.; Grossman, L.; Johnson, M.L.; Burnett, D.S. Determination of trace element mineralliquid partition coefficients in melilite and diopside by ion and electron microprobe techniques. Geochim. Cosmochim. Acta 1989, 53, 3115-3130. [CrossRef]

34. Nash, W.P.; Crecraft, H.R. Partition coefficients for trace elements in silicic magmas. Geochim. Cosmochim. Acta. 1985, 49, 2309-2322. [CrossRef]

35. Chu, M.F.; Wang, K.L.; Griffin, W.L.; Chung, S.L.; O’Reilly, S.Y.; Pearson, N.J.; Iizuka, Y. Apatite Composition: Tracing Petrogenetic Processes inTranshimalayan Granitoids. J. Pet. 2009, 50, 1829-1855. [CrossRef]

36. Hoshino, M.; Kimata, M.; Shimizu, M.; Nishida, N. Minor-element systematics of fluorapatite and zircon inclusions in allanite-(ce) of felsic volcanic rocks from three orogenic belts: Implications for the origin of their host magmas. Can. Miner. 2007, 45, 1337-1353. [CrossRef]

37. Belousova, E.A.; Griffin, W.L.; O’Reilly, S.Y.; Fisher, N.I. Apatites as an indicator mineral for mineral exploration: Trace-element compositions and their relationship to host rock type. J. Geochem. Explor. 2002, 76, 45-69. [CrossRef]

38. Roeder, P.L.; MacArthur, D.; Ma, X.D.; Palmer, G.R.; Mariano, A.N. Cathodoluminescence and microprobe study of rare earth elements in apatite. Am. Miner. 1987, 72, 801-811.

39. O'Reilly, S.Y.; Griffin, W.L. Apatite in the mantle: Implications for metasomatic processes and high heat production in Phanerozoic mantle. Lithos 2000, 53, 217-232. [CrossRef]

40. Kogarko, L.N. Alkaline Magmatism and Enriched Mantle Reservoirs: Mechanisms, Time, and Depth of Formation. Geochem. Int. 2006, 44, 3-10. [CrossRef]

41. Turner, J.S.; Campbell, I.H. The influence of viscosity on fountains in magma chambers. J. Pet. 1986, 27, 1-30.

42. Parsons, I. (Ed.) Origins of Igneous Layering; NATO ASI Series C196; D. Reidel Publishing Company: Dordrecht, The Netherlands, 1987; ISBN 978-90-481-8435-4.

43. Sparks, R.S.J.; Huppert, H.E.; Koyaguchi, T.; Hallworth, M.A. Origin of modal and rhythmic igneous layering by sedimentation in a convecting magma chamber. Nature 1993, 361, 246-249. [CrossRef]

44. Bartlett, R.W. Magma convection, temperature distribution and differentiation. Am. J. Sci. 1969, 267, 1067-1082. [CrossRef]

45. Spera, F.J.; Oldenburg, C.M.; Christensen, C.; Todesco, M. Simulations of convection with crystallization in the system $\mathrm{KAlSi}_{2} \mathrm{O}_{6}-\mathrm{CaMgSi}_{2} \mathrm{O}_{6}$ : Implications for compositionally zoned magma bodies. Am. Miner. 1995, 80, 1188-1207. [CrossRef]

46. Cawthorn, R.G. Layering Intrusions. Developments in Petrology; Elsevier Science B.V.: Amsterdam, The Netherlands; ALausanne, Switzerland; New York, NY, USA; Oxford, UK; Tokyo, Japan, 1996.

47. Tegner, C.; Cawthorn, G.; Kruger, J. Cyclicity in the Main and Upper Zones of the Bushveld Complex, South Africa: Crystallization from a Zoned Magma Sheet. J. Pet. 2006, 47, 2257-2279. [CrossRef]

(C) 2018 by the author. Licensee MDPI, Basel, Switzerland. This article is an open access article distributed under the terms and conditions of the Creative Commons Attribution (CC BY) license (http:/ / creativecommons.org/licenses/by/4.0/). 